\title{
Batek playing Batek for tourists at Peninsular Malaysia's national park
}

\author{
Kirk Endicott \\ Department of Anthropology, 6047 Silsby Hall, Dartmouth College, Hanover, \\ NH 03755-3547, USA \\ kirk.m.endicott@dartmouth.edu
}

\section{Lye Tuck-Po}

Anthropology and Sociology Section, School of Social Sciences, Universiti Sains Malaysia, 10800 USM, Pulau Pinang, Malaysia

tplye@yahoo.com

\section{Nurul Fatanah Zahari}

Prime Minister's Department, Block B4, Parcel B, Federal Government Administrative Centre, 62502 Putrajaya, Malaysia

nurulfatanah@yahoo.com

\author{
Alice Rudge \\ Department of Anthropology, University College London, 14 Taviton Street, \\ WC1H 0BW, UK \\ alice.rudge@gmail.com
}

\begin{abstract}
Batek are a foraging-trading people living in and around Peninsular malaysia's largest national park, taman Negara. In recent years some of their semipermanent camps near the park headquarters at kuala tahan have become tourist attractions. Batek residents allow groups of malaysian and foreign tourists to visit, and they demonstrate some of their specialised skills, including shooting blowpipes and making fire with rattan vines and dry wood, as well as selling handicrafts. In this article we examine the reasons why some Batek participate in the tourist business, how they integrate it into their overall economy, and how they preserve their distinctive cultural values and practices while offering a simplified picture of their culture to curious outsiders.
\end{abstract}

Keywords: Batek, Peninsular malaysia, economy, tourism, cultural resilience 
The drone of outboard motors breaks the calm of the tropical afternoon. Soon two long motorised boats appear downstream and turn towards the gravel bar below the Batek camp. The drivers beach the boats and help their passengers, about a dozen Asian and European tourists, onto the shore (see Figure 1). In the Batek camp on the bluff above, a few children gaze curiously at the new arrivals, but most people feign disinterest. The tourists trudge up the steep riverbank behind the two Malay drivers, who are their tour guides, and then stroll around the camp, observing and photographing the Batek residents lounging around the camp or making miniature blowpipes in front of their lean-tos. The guides answer the tourists' questions and arrange for one of the young Batek men to demonstrate the use of the blowpipe, the primary hunting weapon in the rainforest. After the Batek man shoots a few unpoisoned darts into a board attached to a tree, impressing his audience, the tourists each take a turn. Batek children in the background, amused at the tourists' awkward attempts to hit the target, whisper and giggle. The guides then arrange for a couple of Batek boys to demonstrate how to make fire by rapidly sawing a split piece of rattan vine back and forth across a piece of dry wood. The tourists watch with polite interest and apparent appreciation. Some of the visitors then approach the shelters where Batek display sets of miniature blowpipes and quivers of unpoisoned darts for sale. The young son of a German couple excitedly selects a blowpipe, which he says he had been hoping to get for a long time. Their purchases made, the tourists and guides return to the boats, which soon disappear up the river with a roar. With that, the Batek residents of the camp have completed their performance-playing themselves for the entertainment of tourists.

Cultural tourism in which tourists visit settlements of indigenous people, including some hunter-gatherer communities, has long been popular in various parts of the world (see, eg, Butler \& Hinch 2007; McLaren 1998; Picard \& Wood 1997; Stanley 1998; Bolaane 2013; Cohen 2011; Hamilton 2006; Hitchcock \& Brandenburgh 1990; Hüncke \& Koot 2012; Koot 2013; Tonnaer 2010; Waitt 1999). Without denying that forced compliance sometimes occurs, the reasons indigenous groups participate in such encounters can range widely, from economic benefits to political empowerment to the desire to educate outsiders about themselves and their ways of life. Whether these interactions revive and revitalise traditional practices or destroy them depends on the particular circumstances of the interactions between the hosts and their guests (Cohen 1988; Dentan \& Rawski n.d.:8-10; Greenwood 1977; McLaren 1998).

In this article we examine how Batek hunter-gatherers deal with tourism in Peninsular Malaysia's largest national park, Taman Negara. We focus especially on tourist visits to Batek camps on the fringes of the park, led by Malay 
Figure 1 tourists arriving at a Batek tourism camp on the tembeling river, taman negara, in 2010. Photo by Lye tuck-Po.

guides, and organised by tour businesses owned and run by (mostly) Malay entrepreneurs. We try to determine the reasons why some Batek participate in these encounters and what shapes their presentation of themselves to the visitors. We also consider whether the Batek are being exploited by tourists or tour guides. We argue that Batek interactions with tourists can best be understood in the context of their history of taking advantage of opportunities emanating from the outside world while steadfastly maintaining their autonomy, core values, and preferred way of life. The traditional Batek strategy of keeping multiple economic opportunities open but not becoming dependent upon any one of them may have been a response to resource fluctuations in the rainforest (Lye 2013), but today it also allows them to deal with the insecurities they face in the Malaysian state. Like many other hunter-gatherers, they have to deal with land expropriation, resource degradation, and pressures to give up culture and identity. We argue that 'playing native' for tourists allows them to exploit external expectations of them while enabling them to resist assimilation.

This article draws on long-term observations dating back to Endicott's 1971-1973 fieldwork (mostly in Kelantan), during which Batek did occasional work as guides and porters, but tourism generally was not promoted by the 
Malaysian authorities as a source of foreign exchange (see below). This had changed by the time of Lye's fieldwork in Pahang from 1993 onwards, when boatloads of tourists would stop at selected Batek venues on a daily basis, and Batek were-often angrily-negotiating the terms of their participation with Malay guides and the park authorities. By the time of Nurul's (2007-2008) and Rudge's (2014-2015) fieldwork (both in Pahang), tourism had become naturalised, with established habits and routines. Both Endicott and Lye have made multiple return visits of varying durations, with the most recent being Lye's in 2016. All the authors have observed the intercultural 'encounters' (Tonnaer 2010) between Batek, guides and tourists in various locations, sometimes jointly (Endicott and Lye; Lye and Rudge) in the same locations, and all have discussed tourism with the same Batek groups, but only Nurul focused on tourism as a research topic. We all used the research method of participant observation, and Nurul also used questionnaires. Our long-term perspective enables us to confirm and interpret Batek responses through a historicalcultural lens. It thus affords the opportunity to examine how this exemplary immediate-return society — based on egality, sharing and autonomy-draws on their cultural resources to deal with tourism.

\section{The Batek}

The Batek,1 who number over 1500 people, are one of the 20 or so culturallinguistic groups of Orang Asli ('Original People') of Peninsular Malaysia (Endicott 2016). Their economy is based on hunting and gathering and collecting forest products, such as rattan and aromatic woods, for sale. They may also engage in small-scale farming and day labouring. Most Batek highly value freedom of movement, independence, and variety in their economic activities (Endicott 1984, 1995). Batek society is highly egalitarian, and they value individual and group autonomy. There is no political hierarchy, although there are nominal 'headmen' (penghulu or batin) appointed by the Department for Orang Asli Development (JAKOA) to mediate between groups of Batek and the government. These headmen have no authority within the group.

Until about 1980, the Batek lived in a large area of rainforest mostly in the watersheds of the Lebir River in Kelantan and the Tembeling and Kechau Rivers in Pahang, with a small group located in Terengganu (see

1. The indigenous people living in Taman Negara generally call themselves Batek. They include members of Batek 'Iga', Batek De' and Batek Te' subgroups, but they do not generally distinguish themselves by these divisions. 
Batek PLaying Bazek For toUrIS

Figure 2 map of the Batek territory in the states of Pahang, kelantan, and terengganu in

Peninsular malaysia. map by Lye zuck-Po. 
Figure 2). Most of Taman Negara, the $4343 \mathrm{~km} 2$ national park, lies within the Batek's traditional territory (Lye 2011). Taman Negara is mostly covered with lowland tropical rainforest, where Batek normally live, but it also contains a mountainous area centred on Gunung Tahan, the tallest mountain in Peninsular Malaysia and one of the park's major trekking destinations (Lye 2004:4). From the 1980s onwards much of the Batek's territory outside Taman Negara was selectively logged (which allows forest to regenerate) or clear-cut and converted to oil palm and rubber plantations. Now most Batek maintain settlements on the edges of the park that serve as base camps where individuals and households may keep houses, store possessions, and return at will (Lye 1997:390-428), but people also move in and out of temporary forest camps from time to time (Endicott and Endicott 2008; Lye 2004). About half of the Batek live inside the park at any one time. Inside the park, subsistence activities are subject to wildlife regulations, but the Batek may move around freely (Lye 2002).

\section{Assimilation pressures and Batek resistance}

The appeal of the Batek as a tourist attraction depends upon their maintaining their identity as 'close to nature', a tribal hunting and gathering people who are at home in the tropical rainforest (Lye 2011). The Batek are happy to oblige. Historically they referred to themselves as batck həp, 'people of the forest', and they saw their presence and actions as essential to the continuing existence of the forest (Endicott 1979; Lye 2004; Nurul et al 2011). They followed an elaborate set of prohibitions believed to maintain positive relationships among people, the environment, and the superhuman beings controlling the forces of nature. They considered their rituals necessary to induce the superhuman beings to bring on the honey, flowers, and fruit seasons and to cure serious illnesses. They believed that if the forest were ever destroyed or if they were removed from it, superhuman beings would destroy the world in an all-encompassing flood of water welling up from the underworld (Endicott 1979:53; Lye 2004:27-42). This worldview is still implicit in Batek actions and behaviours, but the religion is now kept secret from outsiders (see below).

For the last few decades, the Malaysian government has promoted international tourism as one component of its push to become a fully developed nation by the year 2020. Although the distinctive cultures of the Orang Asli and other indigenes (in Sabah and Sarawak) are deemed to be valuable tourist attractions, the government has been working hard since the 1980s to assimilate all Orang 
Asli into the rural Malay population (Dentan 2003; Dentan et al 1997; Nicholas 2000; Nobuta 2009). The reason for this ambivalence is political. At the time of independence in 1957, Malays were mostly rural farmers or fishermen and lagged behind the Chinese and Indians economically. To address this problem, the Malay-dominated federal government granted Malays privileged access to places in educational institutions, scholarships, jobs, and the like. These 'special privileges' were enshrined in the Constitution, and, when the states of Sabah and Sarawak in Borneo were added in 1963 to form the Federation of Malaysia, they were extended to the Native Peoples of Borneo, but not to the Orang Asli. The government justified the special privileges of the Malays and Borneo Natives by claiming that they were the indigenous peoples of Malaysia, by contrast with other ethnic groups (Idrus 2011b). Orang Asli, however, are generally acknowledged to be descended from the earliest inhabitants of the peninsula and arguably have an even better claim to 'special privileges'. As Nobuta (2009:xxviii) writes, 'Malay politicians consider the existence of the indigenous Orang Asli as a nuisance. Their existence means that the Malays are "migrants and latecomers". From the point of view of Malay politicians and bureaucrats, the solution to this problem is to assimilate the Orang Asli into the Malay population, so they will be merely another subgroup of rural Malays.

Assimilation efforts are implemented through the process of 'development', by which is meant getting Orang Asli to settle in permanent villages, moving them out of subsistence economies into cash cropping and wage labour, and inducing them to adopt the language, customs and religion of Malays (Islam), which are the legal criteria for being classified as Malays. Some groups of Orang Asli have succumbed to these government pressures, in part because they have been accompanied by disruption of their old ways of life (see, for example, Nobuta 2009). According to the Malaysian constitution and land laws, Orang Asli have no land rights even in areas where their ancestors have lived for countless centuries. Thus, after the interior of the peninsula was opened up for logging and the development of plantations in the 1970s, most Orang Asli lost the land and resources necessary for pursuing economically and politically independent lives. The precursor department to the Department for Orang Asli Development was charged with moving the displaced people into 'regroupment schemes', where families were conditionally allocated small plots of land and expected to make their living by growing cash crops, such as rubber. The result has been that a large portion of the Orang Asli population now live in rural slums and are officially classified as orang termiskin, the 'poorest of the poor' (Dentan et al 1997:117-141; Idrus 2011a:68). 
The Batek have partially escaped these assimilation pressures for the simple reason that they still have a sizable tract of rainforest, contained in the national park and the partially logged forest outside it, that serves as a refuge to which they can withdraw during times of tension with the authorities and other outsiders (Dentan 1992:221-223, 240-241). As mentioned above, almost the whole of Taman Negara is within the ancestral home area of the Batek. They also have the advantage of a relatively benign park administration in the Department of Wildlife and National Parks (DWNP). The DWNP finds the Batek to be a handy source of labour for various purposes, and their existence as a tourist attraction is consistent with the department's aim of supporting tourism in the park. At the same time, the JAKOA does not implement programmes inside the park, although they do extol the positive benefits of development to the Batek.2 Thus, the Batek fall between the cracks in the government's assimilation programmes (Lye 2011). These unusual circumstances make it possible for the Batek to participate in the tourism industry to some extent without giving up their freedom and way of life.

\section{Previous contacts with outsiders}

Until about 1920, the Batek, like most other Orang Asli, were subject to slave raiding by Malays, both local Malay villagers and professional raiders from Sumatra (Dentan 2008; Dentan et al 1997; Endicott 1983). Some Batek hid in the interior of the forest and avoided all contact with outsiders, while others entered into subservient relations with Malay villagers in return for some protection. Some local Malay leaders considered the Batek their slaves, although the Batek moved freely and traded forest products to the villagers (Miklucho-Maclay 1878; Skeat \& Blagden 1906; Waterstradt 1902:5; cf. Wells 1925:99-100, 128-132 on the Batek Tanum). As recently as 1955, Batek living in the Tembeling River watershed in Pahang, perhaps traumatised by the Japanese occupation during the Second World War and the Communist insurrection (the 'Emergency') that followed, still avoided contact with outsiders (Lye 2004:102-108; Needham 1976; van der Schot 1986:18-19).

2. We should note that Orang Asli development is no longer the hegemonic responsibility of JAKOA, which is now focused on service-delivery. Many of its original functions have been distributed to the standard government agencies responsible for them. For example, health care is now the responsibility of the Federal-level Ministry of Health, which has led to better oversight and improvements in the Batek's health status, although problems in maintaining consistent standards still bedevil the service. 
Although Batek can survive without contact with outsiders (Endicott \& Bellwood 1991), they like to trade for such things as metal tools, tobacco, sugar and cultivated foods whenever they can safely do so. They, and other Orang Asli, have been the main suppliers of non-timber forest products, such as resins, to the outside world for thousands of years (Dunn 1975). Since about 1960 rattan (Calamus spp.) has been the most common forest product supplied, and after about 1980 eaglewood (Malay gaharu; Aquilaria spp.), a fragrant wood used for incense and perfume, has also been an important trade good.

After the danger of slave raiding ended, Batek occasionally worked for Malay farmers, helping them harvest their crops in return for a small share of the crop. Batek also worked as guides for outsiders travelling in the forest, such as mineral prospectors. Since the mid-1950s Batek have also had contact with government officials, mainly staff of the DWNP and JAKOA, and, more recently, with Muslim and Christian missionaries. Contemporary interactions with outsiders are more complex, but are still informed by strong notions of difference between them and outsiders ( $g o p)$.

\section{Batek contacts with tourists on the Tembeling River}

Batek involvement in tourism has a long history. As people reminded Lye in the 1990s, quite a number of them helped the park authorities set up the original infrastructure, including establishing trails and building wildlife observation 'hides'. There is strong evidence that this involvement goes back to the 1950s, during C.S. Ogilvie's tenure as park superintendent (Lye 2004:107-108). Until today, many tourist trails in Taman Negara follow or criss-cross the original Batek trails and trade routes. This history partially explains why the Batek feel in some sense proprietorial towards Taman Negara tourism: they were there at the beginning and helped to make it happen.

Since the 1960s, Batek involvement in tourism has taken a different shape. It started when a few men began to work as porters for parties of tourists attempting to climb Gunung Tahan (Zanisah et al 2009:3). In those days the only way to reach park headquarters at Kuala Tahan was by boat from Kuala Tembeling, where the Tembeling River flows into the Jelai River. In March of 1973, when Endicott visited, there was a Batek camp within the grounds of the park headquarters. Park officials employed some of the Batek staying there for specialised work, such as clearing trails, tagging animals and portering for mountain climbers. Tourist visits increased steadily from 1970 onwards, but especially following the redevelopment of park headquarters from 1980 to 
1992. This period also saw the move towards privatisation of certain tourism facilities in line with overall government policy on the public sector. This opened avenues for private operators to provide services to tourists (Shuib 1995:41). Another significant development was the completion of a road from Jerantut to Kuala Tahan around 1999, which enabled faster access to the park (Lye 2002:169-170).

Not much is known about visitors to Taman Negara in earlier decades. Park records were sketchy, and any that existed before 1971 were lost in a flood that breached the banks of the Tembeling River. Shuib, possibly referring to these early years, reports that visitors were mainly 'researchers, specific interest individuals, hard core outback enthusiasts and nature lovers' (1995:40). Official DWNP visitor statistics begin with 1980. These show that Taman Negara attracted roughly equal numbers of local and foreign tourists, with most foreigners being Europeans and Singaporeans. Table 1 shows the increasing number of Malaysian and foreign tourist visitors to the park between 1971 and 1995.

table 1. average numbers of caman negara visitors per annum*

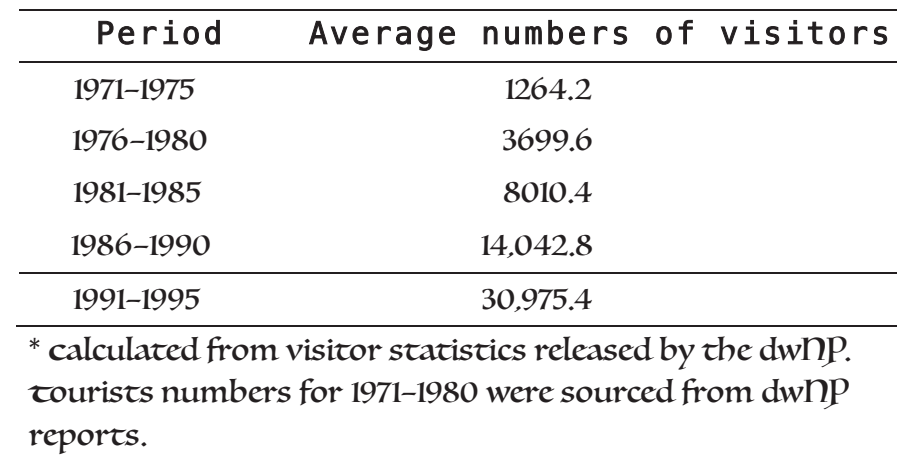

A slightly more fine-grained picture is obtained from a snapshot survey of 230 tourists in 2007 (Daud \& Rahman 2011). This survey showed that most visitors were relatively young $(59.8 \%$ below age $31 ; 92.7 \%$ below age 41$)$ first-time visitors $(88 \%)$, who went to Taman Negara for 'new experiences' $(87 \%)$. About half of the tourists were foreign (47.5\%), and over half were women (56.6\%). Just over half (51.1\%) of the tourists visiting Taman Negara went on their own rather than as part of an organised tour. The most popular activities were taking the canopy walkway through the treetops and jungle trekking. Visiting Batek camps/settlements was ranked fifth overall in the list of activities that tourists engaged in (39\%). This was especially popular with young local women.

Tourist visits to the Batek settlement of Kuala Yong, 15 minutes by boat 
Figure 3 tourists posing with a Batek man, 2010. Photo by Lye zuck-Po.

from the park headquarters, began in the mid-1980s as part of some package tours. This was the period when many services were being privatised, and local Malay villagers were given priority to develop the tourism businesses that were emerging, such as accommodation facilities, transportation and tour guiding (Shuib 1995:41). The village that most benefitted from this development has been Kuala Tahan (located directly across the river from Taman Negara headquarters). For villagers in this rural area, tourism offered unprecedented economic opportunities to replace traditional agricultural work (Shuib 1995:43). Lye's observations, comparing the early 1990s to 2014, confirm that most of the tour guides in the earlier phase were indeed locals, though some later moved on to other business pursuits.

Initially, tours to Batek camps offered little more than the chance to observe and photograph the Batek. Since about the mid-1990s, other components such as the blowpipe-shooting demonstration and fire-making were added. Initially the rate of compensation was not fixed. As tourist visits became more disruptive in the mid-1990s, however, Batek resentment at being treated as a human zoo increased (see below). They had long been represented by the official authorities as 'people of nature', but this was possibly the first time they were put on view on a large scale (see Figure 3). So Batek leaders began 
to negotiate with the guides and the park authorities for more standardised compensation and better scheduling of tours. These negotiations resulted in the present system.

Since about 1990, the Batek have become one of the attractions, like wildlife, that tour companies have promoted to potential visitors to Taman Negara. Their advertisements describe the Batek as shy, gentle, nomadic, hunting and gathering people who live close to nature. The emphasis is on how very different they are from members of modern industrialised societies, a common theme up until the present day.3 During the 1990s, more Batek sites were included in the tours. Some of the tour guides encouraged Batek to make their 'tourist camps' in more accessible locations. These camps were otherwise little different from other Batek camps. By enabling tourism displays in selected locations, the Batek were also channelling tourism away from other locations where drop-in visits were less welcome to the residents. Craft sales were added to the repertoire, and the rate of compensation became standardised.

During this period, young Batek men also became employed as porters, boat drivers, workers in a fish conservation project, and guides, among other jobs. Their superb tracking and navigational skills (Lye 2008, 2016) coupled with their overall concern for the safety of the tourists give them a natural advantage over the Malay guides. Whenever they discussed their guiding work, they stressed their ability to take care of the tourists and for validation pointed out how well they had looked after us during our fieldwork. However, they have not developed Batek-owned and operated businesses (Zanisah et al 2009:4-5, 10), although some Batek say that they wish they could look for tourists on their own, without going through the tour companies. What holds them back is their inability to communicate with the tourists in English. Success in developing cultural tourism enterprises might promote the larger goals of 'economic independence, self-determination, cultural sovereignty, and the maintenance of indigenous traditions' (Bunten 2008:383), but it is uncertain whether commitment to entrepreneurism would be consistent with the maintenance of an autonomous, economically flexible, egalitarian hunting and gathering way of life.

3. For example, one tour company currently starts its advertisement thus: 'See how the aborigines live in a totally different way from us. Know these people; their villages, houses, and activities. They live in very basic lifestyle' (Mohd \& Azrul 2015). 


\section{The process of hosting tourists}

In 2004, when Lye and Endicott visited, there was a special tourist camp (Tom Dari?) a few miles upstream from Kuala Tahan on the riverbank opposite Taman Negara. People told us that as many as 100 tourists visited the camp some days (in recent years these numbers have gone up three- or fourfold). During the rainy season, roughly late November through January, few tourists come, and many of the residents move into forest camps where they can live entirely off hunting, gathering and fishing, while others may move to forestproduce collection areas. In the tourist camp they lived in lean-tos, similar to those used in other forest camps. There were 16 of these in two clusters, not all of them occupied at the time. Families moved in and out of the camp, some in transit to other camp-groups inside and outside the park and some arriving to join the Dari? group (see Lye 1997:202-257 for details of the Batek's overall mobility patterns).

The programme presented at Dari? consisted of the now standard demonstrations of blowpipe shooting and fire-making together with the sale of handicrafts, including miniature blowpipes, darts and incised bamboo hair combs. The Batek treat the cultural performance as a group effort. Their ways of dividing profits indicate interesting compromises between maintaining equality and rewarding individual effort. Entrance fees to the camps were originally divided equally among all the families resident in the camp at that time. Later the money received for blowpipe-shooting and fire-making was kept by those who did the performances, thus encouraging turn-taking. These variations-always vulnerable to abuse - show Batek trying to maintain egalitarian principles of giving everyone a chance, though it is not yet clear how successful they are. The easy distribution of income does not seem to have disrupted the Batek's mobility patterns. Although there is a core group of households that consistently participates in tourism, other households move in and out of the tourist camps at will.

Handicrafts are manufactured by the families in camp, either by women or by women and men working together (see Figure 4). Other families living elsewhere may send their products to relatives in the tourist camps to sell for them. The sellers get up to MR30 for each set of blowpipe and darts. Selling handicrafts to outsiders continues a long-standing practice that began in colonial times, when officials assembled collections of artefacts and specimens (see, for example, Schebesta 1973 (1928) for descriptions of his collecting activities). Batek readily adjust their production to changes in demand. For example, in the early 1970s, Lebir River Batek made and traded rolls of palm 
Figure 4 Batek man making a miniazure blowpipe while his wife makes darts, 2004. Photo by kirk Endicote.

thatch to Malays living downstream, who used the thatch to roof their houses. After the demand for thatch roofing diminished, the Batek turned to trading rattan and fragrant wood. None of these earlier activities has been supplanted by tourism, and Batek may still collect or make products on commission.

In 2007-2008, Nurul surveyed 70 Batek men and women (most of the adult population) living in the vicinity of Kuala Tahan to find out how many participated in various tourist-oriented activities. The results are summarised in Figure 5. These findings show that by far the highest percentage of people worked making handicrafts for sale (77\%), followed by giving demonstrations for tourists $(40 \%)$. It is significant that these are the activities over which the Batek have the most control, though even these activities are not always free from the involvement of middlemen. The other activities require getting jobs or short-term contacts with outside organisers or officials. Although not shown on this graph, just over four times as many men as women took part in the blowpipe and fire demonstrations. 
Figure 5 graph showing the percentage of the sample population involved in the tourist industry, conservation activities, and research projects in taman hegara

\section{Maintaining the Batek mystique}

Batek tourist camps reflect a Malay stereotype of the Batek as well as what guides think tourists expect to see (MacCannell 1973; Tonnaer 2010; Urry 1990). For example, the guides advise the Batek to conceal signs of modernity, such as boom boxes and flashlights. Tourist guides present them as noble savages', primitive but clever in jungle lore, with some cultural symbols and behaviours highlighted, exaggerated, and even fabricated when guides reach the limits of their knowledge of the Batek.

Despite being willing to display the more mundane features of their culture to tourists, Batek now conceal their religious beliefs and rituals from most outsiders. Until the 1970s, Batek at least in Kelantan were not self-conscious about letting outsiders observe their rituals. But this had changed by the 1990s, apparently in reaction to pressures by missionaries to convert them to Islam. Nowadays some Batek deny that they have a religion when asked about it by outsiders, at least in the presence of Malays (van der Schot 1986:24). 


\section{Batek responses to the tourism business}

When asked, Batek living in the tourist camps generally express positive feelings about participating in tourism. Most are willing to present aspects of culture to tourists in return for money. They also enjoy observing the tourists and making sarcastic observations about them, sometimes loudly in the tourists' presence. Tourist responses to the Batek range from polite interest (and respectful distance) to ethnocentrism. For example, both local and foreign tourists still make derogatory remarks about the Batek at various camps, seemingly indifferent to Batek sensitivities. The potential of the tourist encounter to be mutually educational is shaped by the tour guides, many of whom still recycle erroneous stereotypes and, at their worst, exhibit proprietary behaviour towards the Batek. Batek find the guides' presentations hilarious, hurtful, or insulting according to context.

Nurul surveyed 70 Batek men and women living in the vicinity of Kuala Tahan on their attitudes regarding the potential benefits and disadvantages of interacting with tourists. Figures 6 and 7 summarise her findings.

Figure 6 graph showing percentages of Batek who agree and disagree that certain aspects of tourism in taman negara are beneficial to them 
Figure 6 shows that a large majority (93\%) appreciates the opportunity to make money through participation in tourism. By contrast, a large majority $(83 \%)$ do not agree that the development of the infrastructure is beneficial to them. They are divided roughly evenly in their views of the increased opportunities for work and for the promotion of their culture. Possibly this implies that they do not see receiving tourist visitors to their camp as work, but rather as easy money. And jobs that they do classify as 'work', such as driving boats and guiding tourists, are limited to men, only a small number of whom are employed at any time. On the other hand, improvements in the infrastructure have often been threatening to the rainforest and to Batek freedom. For example, Batek are now forbidden to camp along the Tahan River near park headquarters, which has forced them to camp farther up the Tembeling River.

Figure 7 graph showing percentages of Batek who agree and disagree that certain aspects of tourism in taman negara are detrimental to them

Figure 7 shows a fairly consistent pattern, namely, that only about 25 per cent of respondents were disturbed by the noise/discomfort, personal disruption, discrimination/cheating, denial of rights and cultural degradation that might result from participation in the tourist industry as currently constituted. These 
results appear to be influenced by the particular moment in which the study was done. In the mid-1990s, for example, Batek did frequently complain about tourist intrusions into their daily lives. By the time of Nurul's study, practices of compensation and mutual consideration had been established by the original participants (Batek leaders and Malay tour operators), and complaints had accordingly lessened.

On the whole, Batek feelings about tourism are ambivalent. On the one hand, they participate willingly and claim to welcome tourism. This is consistent with how they play on outsiders' stereotypes of them as denizens of the forest, close to nature, and akin to animals and spirits. For example, Batek have long carried on trade in herbal and magical medicines based on their reputation as experts on forest plants and animals, and this trade continues to flourish. On the other hand, they are sensitive to how they are presented and represented by outsiders. As they told Lye in the 1990s in response to being treated as a human zoo, "we are not animals'. This is an important cultural theme not just in the context of tourism. Batek rituals stress a strong distinction between humans and animals and the need to keep the boundary distinct. They, the people, may be part of the forest yet they are not quite 'of nature'; they are at risk of breaking taboos that will anger the spirits and natural forces. When expressing resentment towards terms of abuse that they hear from outsiders, as well as the tour guides' insulting images of their way of life, they often reiterate this theme: they are people who cook their food, not animals that eat food raw.

\section{The question of exploitation}

From an economic perspective, one could argue that the tour guides are exploiting the Batek by not giving them the full value of their participation in the tour business. Batek have no way of knowing what their participation is really worth, but they do feel exploited at the local level. Since the mid-1990s, they have often complained to Lye and Rudge of being short-changed by the Malay guides and of being passed over for the lucrative mountain-guiding jobs. They also complained about photographers and filmmakers not compensating them for participating in shoots; they were aware that images may acquire value as they move into world commodity markets and that they could not control this process or claim a share of profits. At the very least, they insisted, they should be paid for their labour.

Nevertheless, Nurul's survey showed that only 20 per cent of her respondents felt that they were subjected to discrimination or cheating. A Batek man 
explained to Lye in 2010 that the guides' behaviour had improved, but this seems to depend on how closely Batek are working with them. Batek do have seasoned tactics of negotiation and confrontation honed over generations of bargaining with buyers of forest products and playing one buyer off against another, which they may use to deal with the tourism entrepreneurs. Why they tolerate being cheated is, however, an issue that needs further investigation.

The ultimate check on exploitation is that, for the Batek, participation in the tourism industry is voluntary. If the level of exploitation became too onerous, they could simply refuse to 'show up' during the tourist season. They have alternative sources of food (hunting and gathering) and income (eg, forest product sales, wage labour). As we mentioned above, only the families who want to participate in hosting tourists do so, and they can leave the tourist camp at any time. For example, in September 2014 most of the group vacated Dari? camp and abandoned tourism after it was visited by missionaries. Similarly, when guides who are renowned for being drunk or rude show up with tourists at the Trenggan River camp, many people retreat into the forest until the coast is clear.

Batek responses to tourism reveal that they have a shrewd appraisal of its benefits, as a direct, unmediated source of income, an 'immediate return' (Woodburn 1982) just for showing up. They have met tourism's demand for labour and standardised cultural performances, while not being consumed by it. Their reactions to tourism are entirely consistent with their skill at projecting what others want to see of them, conforming to a 'public' imaginary while shielding important features of culture from the tourist gaze. Under current conditions, we think it would be inaccurate to say that the guides are seriously exploiting the Batek, although their behaviour is certainly often far from ideal.

\section{9. \\ Conclusio \\ ns}

So far, contact with tourists has had a minimal effect on Batek culture and well-being. Taman Negara remains their home where they can live as they wish. Some Batek continue to live in camps deep in the forest and refuse to move to locations where they would be fully exposed to outsiders. Others move between interior forest camps and peripheral residences. They have merely incorporated performing for tourists and working in tourism-related jobs into their mix of economic activities. Even those living in remoter areas can get the trade goods they desire by making sporadic contact with outsiders or by sending couriers out to trade on their behalf. The Batek told Nurul that they strongly believe 
that as long as they firmly hold on to their own religious beliefs and practices, they will not be easily influenced and carried away by the negative aspects of tourism, a point they had also raised earlier in other contexts with Lye (1994, 2004). Furthermore, according to them, such matters largely depend on the individual alone.

Under current conditions, then, participating in the tourist industry seems to be beneficial to the Batek. However, these conditions are not guaranteed. According to Malaysian laws, Batek have no secure land rights or rights to live in the park, although they are acknowledged to be its 'aboriginal' inhabitants (Hood \& Bettinger 2008:301; Lye 2011). In discussions in the early 1930s, colonial officials reasoned that the future national park (formally enacted in 1938/1939) and other wildlife conservation areas could also serve as land reserves for the indigenous inhabitants of those areas. However, for unknown reasons they were unable to translate these ideas into statutory provisions (Lye 2011). Current policies of the DWNP, which date back to colonial provisions and were reaffirmed in the 1987 Master Plan, permit Batek to live in the park but only to hunt and gather for their subsistence needs (Lye 2002, 2011). Although Batek resent the restrictions on collecting and selling forest products from inside the park (van der Schot 1986:19, 44), these policies are quite enlightened and humane compared to policies in many other countries, where the indigenous inhabitants of areas converted into national parks are brutally expelled, often with disastrous consequences for the displaced peoples (Igoe 2004; Turnbull 1972). However, the policies followed in Taman Negara have no statutory guarantees, and in theory the DWNP could insist on resettling the Batek outside the park (Lye 2002; Hood \& Bettinger 2008:301). This would certainly undermine their autonomy and possibly lead to their becoming fully dependent wards of the state.

This case study has examined interactions between two groups of mobile peoples: mobile hunter-gatherers with their low tolerance for monotony and boredom and mobile tourists seeking 'difference' from their regular routines, with guides and profiteers in the middle dependent on both to show up at the same time and place. Over the years, the industry has become naturalised, with visits to indigenous camps becoming a regular part of the tourist experience in Taman Negara, and encounters being stage-managed to meet as many expectations as possible. Conventionally, given their lack of control over the process, we would expect the Batek to be the victims and for their culture to be seriously destabilised by tourism. In examining indigenous perspectives and long-term behaviour patterns, however, we think that something subtler is happening, with tourism incorporated into the Batek's regular economic repertoire yet so 
far not becoming hegemonic. We believe that the Batek recognise that their circumstances are continually changing, and they deliberately maintain their flexibility and backup plans. Their limited commitment to the tourism industry is consistent with their desire not to be too dependent upon any one means of support, especially when their control over it is limited. Guides and tour operators may set the terms of the tourist encounter, but their success depends on tourists' willingness to visit and the Batek's willingness to be visited. The latter will persist so long as the Batek perceive a benefit from it. Of course, their 'cultural performances' extend to their responses to anthropologists' queries; what they really think about tourism and how they will adapt to its changing pressures and demands remain to be seen.

\section{Acknowledgements}

We wish to thank the Economic Planning Unit of the Prime Minister's Office (EPU), the Department for Orang Asli Development (JAKOA) and the Department of Wildlife and National Parks (DWNP) for granting us permission to conduct research with the Batek. We also thank our many Batek friends for giving us permission to carry out this study and for their generous hospitality and endless assistance. For financial support, Nurul thanks Universiti Kebangsaan Malaysia; Endicott thanks the US National Institute of Mental Health, the University of Malaya, the Australian National University, the Fulbright-Hays Commission, the American Social Science Research Council and the Claire Garber Goodman Fund of Dartmouth College; Lye thanks the Wenner-Gren Foundation for Anthropological Research, the East-West Center, the John D. and Catherine T. MacArthur Foundation, the Japan Ministry of Education and Universiti Sains Malaysia; and Rudge thanks Leverhulme, University College London and the Evans Fund at Cambridge. Lye also thanks the Global South Studies Center of Cologne University and the Humboldt Foundation for writing support and Rudge thanks Universiti Sains Malaysia for institutional support in the course of fieldwork. We are also grateful to Alexis Bunten, Jim Igoe, Lourdes Gutiérrez Nájera, Thomas Widlok, Robert Dentan and an anonymous reviewer for valuable suggestions. 


\section{References}

Bolaane, MMM 2013. Chiefs, hunters and San in the creation of the Moremi Game Reserve, Okavango Delta. Senri Ethnological Studies, 83. Osaka: National Museum of Ethnology.

Bunten, AC 2008. Sharing culture or selling out? developing the commodified persona in the heritage industry. American Ethnologist 35:380-395.

Butler, R \& Hinch, T 2007. Tourism and indigenous peoples: issues and implications. Oxford: Butterworth-Heinemann.

Cohen, E 1988. Authenticity and commoditization in tourism. Annals of Tourism Research 15:371-386.

Cohen, E 2011. Tourism and land grab in the aftermath of the Indian Ocean tsunami. Scandinavian Journal of Hospitality and Tourism 11(3):224-236.

Daud, N \& Rahman, SA 2011. Tourist attitudes towards sustainable tourism: empirical evidence from Malaysian National Park, Taman Negara. IPEDR. 2010 International Conference on E-business, Management and Economics 3:254-258. http://www.ipedr.net/vol3/52-M10023.pdf.

Dentan, RK 1992. The rise, maintenance and destruction of peaceable polity. In Silverberg, J \& Gray, JP (eds) Aggression and peacefulness in humans and other primates. New York: Oxford University Press:214-270.

Dentan, RK 2003. Ideas redeem, but political memories do run short: Islamicization in

Malaysia. Social Justice: Anthropology, Peace and Human Rights 3:153-189. Dentan, RK 2008. Overwhelming terror: love, fear, peace, and violence among Semai of Malaysia. Lanham, MD: Rowman and Littlefield.

Dentan, RK, Endicott, K, Gomes, AG, \& Hooker, MB 1997. Malaysia and the original people: a case study of the impact of development on indigenous peoples. Needham Heights, MA: Allyn and Bacon.

Dentan, RK \& Rawski, F n.d. Much more than a tan to talk about: tourists, Orang Asli, Malay nationalism and commoditized cultural diversification. Keene, NH: Orang Asli Archive, Keene State College.

Dunn, FL 1975. Rainforest collectors and traders: a study of resource utilization in modern and ancient Malaya. Kuala Lumpur: Malaysian Branch of the Royal Asiatic Society.

Endicott, K 1979. Batek Negrito religion: the world-view and rituals of a hunting and gathering people of Peninsular Malaysia. Oxford: Clarendon.

Endicott, K 1983. The effects of slave raiding on the aborigines of the Malay Peninsula. In Reid, A \& Brewster, J (eds) Slavery, bondage, and dependency in Southeast Asia. Brisbane, Australia: University of Queensland Press:216-245.

Endicott, K 1984. The economy of the Batek of Malaysia: annual and historical perspectives. Research in Economic Anthropology 6:29-52.

Endicott, K 1995. Seasonal variations in the foraging economy and camp size of the Batek of Malaysia. In Rokiah, T \& Tan, CB (eds) Dimensions of tradition and development in Malaysia. Petaling Jaya, Malaysia: Pelanduk:239-254.

Endicott, K (ed.) 2016. Malaysia's original people: past, present and future of the Orang Asli. Singapore: National University of Singapore Press. 
Endicott, K \& Bellwood, P 1991. The possibility of independent foraging in the rain forest of Peninsular Malaysia. Human Ecology 19:151-185.

Endicott, K \& Endicott, KL 2008. The headman was a woman: the gender egalitarian Batek of Malaysia. Long Grove, IL: Waveland Press.

Greenwood, DJ 1977. Culture by the pound: an anthropological perspective on tourism as cultural commoditization. In Smith, V (ed.) Hosts and guests: the anthropology of tourism. Philadelphia: University of Pennsylvania Press:129-138.

Hamilton, A 2006. Reflections on the 'disappearing Sakai': a tribal minority in southern Thailand. Journal of Southeast Asian Studies 37(2):293-314.

Hitchcock, RK \& Brandenburgh, RL 1990. Tourism, conservation, and culture in the Kalahari Desert, Botswana. Cultural Survival Quarterly 14 (2):20-24. https://w w w.culturalsurvival.org/ourpublications/csq/article/tourism-conservation-and-culture-kalahari-desert-botswana. Accessed 3 December 2015.

Hood, S \& Bettinger, KA 2008. Indigenous peoples and parks in Malaysia: issues and questions. In Navjot, SS et al (eds) Biodiversity and human livelihoods in protected areas: case studies. Cambridge: Cambridge University Press:289-310.

Hüncke, A \& Koot, S 2012. The presentation of Bushmen in cultural tourism: tourists' images of Bushmen and the tourism provider's presentation of (Hai//om) Bushmen at Treesleeper Camp, Namibia. Critical Arts 26(5):671-689.

Idrus, R 2011a. The discourse of protection and the Orang Asli in Malaysia. Kajian Malaysia 29(1):53-74.

Idrus, R 2011b. Malays and Orang Asli: contesting indigeneity. In Maznah, M \& Aljunied, SMK (eds) Melayu: The politics, poetics and paradoxes of Malayness. Singapore: NUS Press: 101-123.

Igoe, J 2004. Conservation and globalization: a study of national parks and indigenous communities from East Africa to South Dakota. Belmont, CA: Wadsworth/Thomson Learning.

Koot, SP 2013. Dwelling in tourism: power and myth amongst Bushmen in Southern Africa. PhD thesis, Tilburg University, Tilburg.

Lye, TP 1994. Batek hep: culture, nature, and the folklore of a Malaysian forest people. MA thesis, University of Hawai'i at Manoa.

Lye, TP 1997. Knowledge, forest, and hunter-gatherer movement: the Batek of Pahang, Malaysia. PhD dissertation, University of Hawai'i at Manoa.

Lye, TP 2002. Forest peoples, conservation boundaries, and the problem of 'modernity' in Malaysia. In Benjamin, G \& Chou, C (eds) Tribal communities in the Malay world: historical, cultural and social perspectives. Leiden: IIAS and Singapore: ISEAS:160-184.

Lye, TP 2004. Changing pathways: forest degradation and the Batek of Pahang, Malaysia. Lanham, MD: Lexington Books.

Lye, TP 2008. Before a step too far: walking with Batek hunter-gatherers in the forests of Pahang, Malaysia. In Ingold, T \& Vergunst, JL (eds) Ways of walking: ethnography and practice on foot. Aldershot, Hants: Ashgate:21-34.

Lye, TP 2011. The wild and the tame in protected areas management, Peninsular Malaysia. In Dove, M, Sajise, PS, \& Doolittle, AA (eds) Complicating conservation in Southeast Asia: beyond the sacred forest. Durham, NC: Duke University Press:37-61. 
Lye, TP 2013. Making friends in the rainforest: 'Negrito' adaptation to risk and uncertainty. Human Biology 85:417-444.

Lye, TP 2016. Signaling presence: how Batek and Penan hunter-gatherers in Malaysia mark the landscape. In Lovis, M \& Whallon, R (eds) Marking the land: huntergatherer creation of meaning in their environment. Oxford: Routledge:231-260.

MacCannell, T 1973. Staged authenticity: arrangements of social space in tourist settings. American Journal of Sociology 79:589-603.

McLaren, D 1998. Rethinking tourism and ecotravel: the paving of paradise and what you can do to stop it. West Hartford, CT: Kumarian Press.

Miklucho-Maclay, N 1878. Ethnological excursions in the Malay Peninsula - November 1874 to October 1875 (preliminary communication). Journal of the Straits Branch of the Royal Asiatic Society 2:205-221.

Mohd, R \& Azrul, S 2015. Taman Negara: back to nature. http://www.tamannegara. asia/kampung-orang-asli. Accessed 11 December 2015.

Needham, R 1976. Minor reports concerning Negritos in northern Pahang. Journal of the Malaysian Branch of the Royal Asiatic Society 49(2):184-193.

Nicholas, C 2000. The Orang Asli and the contest for resources: indigenous politics, development and identity in Peninsular Malaysia. Subang Jaya, Malaysia: IWGIA/COAC.

Nobuta, T 2009. Living on the periphery: development and Islamization of the Orang Asli. Subang Jaya, Malaysia: Center for Orang Asli Concerns.

Nurul FKZ, Mustaffa, O, \& Salleh, D 2011. Lawad, ye' yo' and tum yap: the manifestation of forest in the lives of the Bateks in Taman Negara national park. Journal of ASIAN Behavioural Studies 1(1):29-40.

Picard, M \& Wood, RE 1997. Tourism, ethnicity, and the state in Asian and Pacific societies. Honolulu: University of Hawai'i Press.

Schebesta, P 1973 (1928). Among the forest dwarfs of Malaya. London: Oxford University Press.

Shuib, A 1995. Tourism in Taman Negara Malaysia: its contribution as perceived by residents of Ulu Tembeling. Akademika 47(July):37-48.

Skeat, WW \& Blagden, CO 1906. Pagan races of the Malay Peninsula, vol. 2. London: MacMillan.

Stanley, N 1998. Being ourselves for you: the global display of cultures. London: Middlesex University Press.

Tonnaer, A 2010. A ritual of meeting: 'sharing culture' as a shared culture in Australian indigenous tourism. La Ricerca Folklorica 61:21-31.

Turnbull, C 1972. The mountain people. New York: Simon and Schuster.

Urry, J 1990. The tourist gaze: leisure and travel in contemporary society. London: Sage.

Van der Schot, WEM 1986. The Batek of Taman Negara: a hunters/gatherers community in a Malay national park. $\mathrm{PhD}$ thesis, Universiteit van Amsterdam.

Waitt, G 1999. Naturalizing the 'primitive': a critique of marketing Australia's indigenous peoples as 'hunter-gatherers'. Tourism Geographies 1(2):142-163.

Waterstradt, J 1902. Kelantan and my trip to Gunong Tahan. Journal of the Straits Branch of the Royal Asiatic Society 37:1-28. 


\section{Batek PLaUIng Batek For toUrIS}

Wells, C 1925. Six years in the Malayan jungle. Singapore: Oxford in Asia Paperbacks, Oxford University Press.

Woodburn, J 1982. Egalitarian Societies. Man 17:431-451.

Zanisah, M, Nurul, FKZ, \& Mustaffa, O 2009. Kesan ekonomi pelancongan terhadap komuniti Batek di Kuala Tahan, Pahang (Effects of the tourism economy on the Batek community at Kuala Tahan, Pahang). Jurnal e-Bangi 4(1):1-12. 